\title{
DETERMINANTS OF FDI INFLOWS IN SIX ASEAN COUNTRIES IN 1998-2016
}

\author{
Iqbal Firdaus $^{1}$, Sri Mulatsih ${ }^{2}$,Iskandar Ahmaddien ${ }^{3}$ \\ ${ }^{1}$ Badan Pusat Statistik \\ ${ }^{2}$ Economics Departemen, Institut Pertanian Bogor \\ ${ }^{3}$ Management Departemen, Universitas Sangga Buana Bandung \\ 1ibaldaus@gmail.com \\ ${ }^{2}$ mulatsupardi@gmail.com \\ ${ }^{3}$ iskandar.ahmaddien@gmail.com
}

\begin{abstract}
Investment is an important element of the growth and the development of economic. Foreign Direct Investment (FDI) is one of the investment sources as an alternative to the Domestic Investment that might be difficult to be fulfilled by a country itself. The increased numbers of FDI inflows to ASEAN countries turns out were not evenly distributed to each country. This research is important to determine the development and determinants of FDI inflows in six ASEAN countries in the period of 1998-2016. From the panel data regression analysis, it can be concluded that the variable levels of corruption negatively affect the FDI inflows, while the level of economic freedom and income per capita has a positive effect on FDI inflows in six ASEAN countries in 1998-2016.
\end{abstract}

Keywords: FDI, economic freedom, corruption, panel data

\section{Introduction}

Foreign direct investment is regarded as an investment that plays an important role in supporting the economic growth in developing countries. The presence of FDI into a country could create new jobs which will reduce the unemployment. The availability of new jobs could increase the domestic productivity, and increase the government tax revenues which in turn will increase the national income so that the economic growth of a country can be better. Good economic growth will increase the market size in the country so as to provide an opportunity for investors to increase the market share and the economies of scale.

ASEAN, which is part of the Asia, provide a large enough role to the total quantity of FDI inflows into Asia. According to the World Investment Report in addition to China and Hong Kong, ASEAN countries are quite dominating the FDI inflows in Asia.
ASEAN give a very large role, reaching nearly one third of the total of FDI inflows Asia. Some ASEAN countries even have been in the list of top 10 Asian countries with the largest FDI inflows in Asia in the period of 1998-2016.

FDI inflows in Asia and also ASEAN continues to increase every year. This can be seen in Figure 1. FDI inflows of ASEAN accounted for nearly a third of total of FDI in Asia. One reason for the high growth cannot be separated from the rapid flow of foreign investment to the countries of this region. ASEAN countries successfully attracted the FDI inflows and make the foreign investors companies as part of their national development strategies to achieve the economic growth. (World Investment Report, 2016).

If we look at the data in more detail, it was only six ASEAN countries that contributes to FDI inflows in ASEAN 
itself. Noted countries such as Indonesia, Malaysia, Philippines, Singapore, Thailand and Vietnam dominate the FDI inflows in ASEAN in the period of 19982016. While countries such as Brunei, Cambodia, Laos, and Myanmar are generally only provide a very small share. The share of the six ASEAN countries can be seen to some point of the period in Figure 2 below.

Inequality would be a question why the state is superior to other countries. In addition to changes in the share contribution of each country in compiling the share of FDI inflows in ASEAN is certainly signify that the dynamics or changes in terms of economic, social and political factors that have affected changes in the inflow of foreign investment toward such ASEAN countries.

Corruption has dangerous consequences, and has become a challenge in the economy almost in all countries. Corruption declines the competitiveness of a country drastically. Corruption can inhibit the inward investment that is essential for the economic growth.

These variables are the indicators that will be further examined in this study along with several other control variables, namely per capita income and the unemployment level. It becomes an interesting thing to study on how the development and determinants of FDI inflows in six ASEAN countries during the period of 1998-2016. Regarding to that issue, the formulation of the problems in this study are:

1. How is the development of FDI inflows in six ASEAN countries over the period of 1998-2016?

2. What are the determinants of FDI inflows in six ASEAN countries over the period of 1998-2016?

\section{Investments}

Tandelilin (2010) stated that investment can be interpreted as a commitment to invest some funds at this time with the purpose of gaining profit in the future. Investing can be associated with the planting of a number of funds in real assets such as land, gold, houses, and other real assets or financial assets such as deposits, stocks, obligation, and other securities. Parties who make investments are called as investors.

Investment is a source of the growth and the development of economic. One of the famous model of economic growth is Harrod-Domar growth theory. According to Todaro (2006), the Harrod-Domar growth model is built based on the experience of developed countries. The model is built based on the advanced capitalist economies. Harrod-Domar growth model explain the important role of investment formation in the process of economic growth of a country. Investment is considered as an important factor because it has two characters or two roles at once in influencing the economy, first, as a factor that can create revenue, meaning that the investment affect the sector of demand. Second, investments can increase the economy production capacity by increasing the stock of capital, meaning that the investment will affect the sector of supply.

Foreign direct investment (FDI) is a type of real investment where investors doing the factory construction, the purchase of goods and capital, recruiting labor force so as to enable investors to make production processes in recipient countries of investment. Foreign direct investment is an investment that plays an important role in the development process of a country, especially in developing countries, through the production process carried out by foreign investors in the recipient countries of investment, which will encourage the creation of new jobs and employment. Furthermore, the production process is also automatically increase the national output, which in turn will boost the 
economic growth in the recipient country of investment (Salvatore, 2014)

Companies from countries investors will direct do the supervision over FDI assets invested in capital importing country. FDI can take several forms, namely the establishment of a branch in capital importing country, the establishment of a company in which companies in the importing country that is solely financed by companies located in the country of the investor to specifically operate in other countries, or put the assets (fixed assets) in another country by the national company of countries investors (Salvatore, 2014).

Subasat (2013) in his study towards the data of FDI inflows of countries in Latin America that used the panel data model found a bad relation of the governance towards the flow of the entry of FDI inflows by a multinational company. Results of the study argued the other studies which states that the bad of governance become an attraction for multinational company

\section{Corruption}

Transparency International defines corruption as the abuse of power that is entrusted for the private gain. Corruption is hurting other people's lives, other people's livelihood and happiness of others depends on the integrity and position of the person in power. This definition covers corruption in both of the public and private sectors.

Corruption Perception Index (CPI) is an instrument of the measurement level of corruption in the country all over the world developed by Transparency International. In the data of Corruption Perception Index, the value of the index has a scale of $0-100$ which has a meaning that if it is getting closer to the number of 100 , then a country is getting more free of corruption. This index issued by Transparency International every year with the number of countries is increasing every year. In 2017 the number of countries that participated as many as 176 countries are much improved compared to when the initial calculation of the CPI in 1998 is just as many as 85 countries.

All the sources of information used to construct the CPI are produced by leading organizations and organization of data collectors. To be included in the $\mathrm{CPI}$, the sources have to measure the overall extent of corruption (frequency and size of corrupt transactions) in the public and politics sector, rank the countries, the perception of corruption is different in each country. The methodology used to assess this perception should be the same for all countries assessed from the source to be selected. The number of surveys and assessments that are included vary from year to year depending on the availability at the time of the development of the index. CPI since 2010 until today was calculated using the data from 13 different surveys or assessments produced by 10 independent organizations as follows:

1. Africa Development Bank-Country Policy and Institutional Assessments

2. Asian Development Bank-Country Performance Assessment Ratings

3. Bertelsmann FoundationBertelsmann Transformation Index

4. Economist Intelligence Unit Country Risk Service and Country Forecast

5. Freedom House-Nations in Transit

6. Global Insights, formerly World Markets Research Centre- Country Risk Ratings

7. Institute for Management Development - World Competitiveness Report

8. Political and Economic Risk Consultancy, Hong Kong - Asian Intelligence

9. World Economic Forum - Global Competitiveness Report

10. World Bank - Country Policy and Institutional Assessments for IDA Countries 
Not all surveys sort the rankings of all countries, due to different coverage of each survey. At least, a country is minimally covered in three different surveys to count the value of its CPI.

Gasanova (2017) in his research found that the low level of corruption in a country become an attractiveness for investors. He divided the country into several categories, countries with low corruption levels and high levels of FDI inflows, countries with low corruption levels and FDI inflows above average, countries with medium corruption level and FDI inflows in intermediate, and countries with high corruption levels and FDI inflows in low.

Sambharya (2015) in his study found that good economic management (monetary policy, fiscal burden, and low corruption may increase the FDI inflows). In addition, the low setting prices and wages also political freedom are also positively related to the increasing in FDI inflows.

\section{Economic freedom}

As an indicator of economic freedom itself, it is expressed in an index called the Economic Freedom Index (EFI) released by the Heritage Foundation since 1995. The Heritage Foundation is a research institute that is long enough to take part both in America and international. The value of the index of economic freedom itself is 0 to 100 , with details as follows:
1. $0-49.9$ The depressed state
2. $50-59.0$ Mostly not free
3. $60-69.9$ Moderate
4. $70-79.9$ Mostly free
5. $80-100$ Free

Mankiw (2007) states that, one of the reasons on why each country has an efficiency level of different production is because it has a different institution. The ideal government should act as a helping hand on the market system, the protection of property rights, implementation of the agreements that have been approved, the promotion of competition, enforcement criminals and other.

Zghidi (2016) in his study in the North African countries found that economic freedom attract the FDI inflows to those countries. Countries that aggressively promote the economic freedom gained the trust of multinational corporations.

Naanwaab (2016) in his study found that economic freedom has a positive and significant impact on FDI inflows in the middle and high income countries. In his study was also found a positive and significant relationship between human development with FDI inflows in all countries.

\section{Per capita Income}

According to Callen (2008) Per capita income indicates the size of the economy of a country and a change in the output of goods and services per individual. In general, per capita income can describe the state of economic prosperity. The higher of the per capita income indicates the welfare of a region. A high per capita income can also describe the high purchasing power and the potential of the host country of consumption.

Benefits of the calculation of per capita income as an economic indicator that measures the level of prosperity of a country's population. Benefits of the calculation of per capita income are as follows (Taufik, 2017):

1. To see the level of welfare comparisons of the people of a country from year to year.

2. As the welfare comparison data of a country with other countries.

3. As a comparison of the level of living standards of a country with other countries.

4. As the data to take policy in the economic field. The per capita income can be used as consideration for taking land considerations to take steps in the economic field. 


\section{Employment and Unemployment}

The concepts and definitions used in employment data through SAKERNAS by the Central Agency of Statistics is "The Labor Force Concept" suggested by the International Labor Organization (ILO). Here is a concept described which is related with the labor force.

1. The labor force is the working age population (15 years and over) who work, or have a job but temporarily absent from work and unemployment.

2. Work is an economic activity undertaken by a person with the intent to obtain or help to earn revenue or profits, at least 1 hour (uninterrupted) during the past week.

3. Unemployment includes labor force that does not work / do not have a job or are looking for work (unemployment definitions used since SAKERNAS 2000).

4. Underemployed are those who worked under normal working hours (less than 35 hours a week), and are still looking for work or are willing to accept the job (formerly called underemployment forced).

5. Total of working hours of all jobs are the length of time in hours that used to work on the whole job, not including the official working hours of rest and hours of work are used to things outside of work during the past week.

Mankiw (2007) states that, unemployment can be divided again into frictional unemployment, structural unemployment and natural unemployment (unemployment due to lack of demand or demand deficiency unemployment). Each of these is described below as follows.

a. Frictional unemployment is the unemployment that is temporary and caused by the constraints of time, information, and geographic conditions between job applicants with a job application opener.

b. Structural unemployment is a state where the jobless seeking employment are not able to meet the requirements specified by the opening of employment.

c. Natural level of unemployment is frictional and structural unemployment coupled with new participants in the labor force in a dynamic economy. The level of natural level of unemployment admits that even with an adequate job, it will not be able to achieve the level of unemployment at the zero point.

Salvatore (2014) in his book "International Economics" explains that, the multinational corporations view the labor factor as a determining factor for them, Multinational Company (MNC) to invest in a country. Since the main purpose of investors inseparable from the search for profit, so that the low cost of labor for the payment become an attraction.

\section{Theorical Framework}

Economic growth requires the availability of capital. Limitations of the fulfillment of the capital development in a country or region can be fulfilled with support from domestic and foreign capital. Foreign investors to invest in a host country or country of destination for investment in this study is six ASEAN countries are expected to pay attention to the circumstances prevailing in the host country.

The level of corruption and the level of economic freedom are expected to affect the amount of foreign capital. In addition, the amount of per capita income as a proxy for purchasing power and unemployment rate as a proxy for low cost labor is also thought to affect the amount of foreign capital coming into the country. Panel data regression analysis is used to find the determinants of FDI inflows variables that can later be used as the basis for the policy of increasing FDI inflows.

\section{Research Hypothesis}

In this study, based on the formulation of the problem as well as a review of 
theoretical and empirical that has been done, it can be arranged hypothesis of the study as follows:

1. The level of corruption that is expressed through the Corruption Perception Index (CPI) has a negative and significant impact on FDI inflows in six ASEAN countries.

2. The level of economic freedom that is expressed by the Economic Freedom Index (EFI) has a positive and significant impact on FDI inflows in six ASEAN countries.

3. Per capital income as a proxy for the purchasing power of the people has a positive and significant impact on FDI inflows in six ASEAN countries.

4. The unemployment level as a proxy for cheap labor has a positive and significant impact on FDI inflows in six ASEAN countries.

\section{Methodology}

\section{Types and Sources of Data}

Type of the data used in this study is secondary data from panel data which is a combination of cross section data and time series data during the period of 1998-2016. According to Firdaus (2018) panel data model is an econometric model that combines data of time series with data of cross section. The implications derived from this combination is the estimation result of panel data model that is more efficient, because of the number of observations for more.

Panel data is used to overcome the problem of limited cross section and time series data to produce the estimation that is more efficient through the increasing in the number of observations which have implications for increasing the degree of freedom. Type of panel data used in this study is a balanced panel of each unit cross section which has a number of observations of the same of time series. The source of research data comes in the form of secondary data from various sources described in Table 1.
The six major ASEAN countries which are the contributors of FDI inflows in Asia in this study are as follows:

1. Indonesia

2. Malaysia.

3. Philippines.

4. Singapore.

5. Thailand.

6. Vietnamese.

The research model is mostly adopted from the research model of Proenca (2005), which examined the factors that influence the spending of foreign tourists. The explanation of the variables of this research and the notation in the research model the following equation:

$$
\begin{aligned}
& \operatorname{RasioFDI}_{\mathrm{it}}=\alpha+\beta_{1} \operatorname{LnCPI}_{\mathrm{it}}+ \\
& \left.\beta_{2} \operatorname{LnEFI}_{\mathrm{it}}+\beta_{3} \operatorname{RasioGDPCap}_{\mathrm{it}}+\beta_{4} \mathrm{l}\right)
\end{aligned}
$$

\section{Analysis method}

The analytical method used is descriptive and quantitative methods. Descriptive method used to assess the dynamics of the variables in the model in six ASEAN countries. Quantitative methods were used in this study is panel data analysis method. This method is used to analyze the factors that affect the FDI inflows which include the level of corruption and economic freedom. Secondary data from six ASEAN countries were analyzed using the computer program, Microsoft Excel and Eviews 9 which then the outputs of the results will be interpreted.

\section{Result and Discussions Determination of Panel Data Model}

There are three types of estimation techniques of the panel data regression model, that are the common effects models, fixed effects models and random effects models. From these models, then will be selected which model is most appropriate to use. According to Firdaus (2018), in the selection of the best models, some of the considerations put forward by experts of econometrics. The consideration for instance states that 
random effects model which has fewer parameters, consequently the degree of freedom is greater than the fixed effects model that has a lot of more parameters, so that the degree of freedom is smaller. However, fixed effects models also have some advantages, such as: fixed effects models can distinguish the individual effects and the effects of time, and fixed effects models also do not need to fulfill the assumption which states that the error component is not correlating with the variable of freedom that is possibly difficult to fulfill.

Selection of the best models made using a formal test. Formal test used to select the best model on panel data regression, that is the Chow test with F statistical test used to select the common effects models of fixed effects model; Breush-Pagan Lagrange Multiplier test is used to select between random effects model or common effects models; and Hausman test to choose fixed effects model or random effects models.

After determining the estimation model, the next step is to choose the appropriate estimation method in accordance with the structure of the residual of variancecovariance. It is useful to determine the appropriate estimation method to be used, whether OLS or FGLS. However, if the chosen model is a random effects model, then the test for the selection of the structure of the residuals of variancecovariance is not necessary to be conducted, because the proper method to estimate the random effects models is Feasible Generelized Least Square (FGLS) (Greene, 2012).

The test stages are as follows:

1. Selection of Structure Estimator of Homoscedastic with Lagrange Multiplier Test

To determine the formed variancecovariance structure, first, it is carried out the election of homoscedastic or heteroscedastic structure estimator with Langrange Multiplier test (LM test). If the obtained structure of the residuals of variance-covariance are homoscedastic, then the estimation method to be used is OLS, whereas if the obtained structure of residuals of variance-covariance are heteroscedastic, it is necessary to proceed with the test Lagrange Multiplier (LM test) on the selection structure of the presence or absence of a cross sectional correlation.

2. Selection of Structure Estimator of Cross Sectional Correlation with Multtiplier Lagrange Test $\left(\lambda_{\mathrm{LM}}\right.$ Test)

The test statistic of $\lambda_{\mathrm{LM}}$ developed by Breusch and Pagan used to determine the matrix structure of residuals of variancecovariance of individual correlated to across individuals (cross sectional correlation) or not.

If the structure of the residuals of variance-covariance is heteroscedastic and there are no cross sectional correlation, the estimation method used is FGLS with a cross section weights. Whereas, if the structure of the residuals of variance-covariance are heteroscedastic and there is a crosssectional correlation, then the estimation method is FGLS with a cross section weights and Seemingly Unrelated Regressions (SUR).

Having obtained the best panel data model along with methods of estimation, it is necessary to check the classic assumption. If the estimation method is OLS, it is necessary to have an assumption of normality, homoscedasticity, non-multicolinearity, and non-autocorrelation. If the estimation method is FGLS, then only need the assumption of normality and nonmulticolinearity. This is because FGLS has accommodated the assumption of heteroscedasticity or inefficient autocorrelation when it is used on OLS (Veerbek, 2004). 


\section{Selection of Panel Data Regression Model}

Stages of regression model selection to choose between the common effects models and fixed effects models, then it will be conducted the test using the Chow test on fixed effects models created by the null hypothesis of common effects model is better than fixed effects models. The test results using the Chow test can be found in the appendix. Based on the calculation results, it is obtained that the value of probability $=0.000$, which is smaller than the value of $\alpha=0.05$, means that the fixed effect model better or reject $\mathrm{H}_{0}$.

Having obtained the fixed effects models, then it is followed by the elections between fixed effects models and random effects models. This test used Hausman test on a formed random effects model, with the null hypothesis of random effects model is better than fixed effects models. The test results using Hausman test can be found in the appendix. Based on the calculation results, it is obtained the value of probability $=0.000$, which is smaller than the value of $\alpha=0.05$, means that the fixed effect model is better or reject $\mathrm{H}_{0}$. Because fixed effects model was selected as the best model of the two other models, the Breush-Pagan Lagrange Multiplier Test (BPLM test) is not necessary to be conducted.

The next step is the selection of the structure of the residuals of variancecovariance to determine the appropriate estimation method to be used in fixed effects models produced, whether homoscedastic or heteroscedastic. Fixed effects model can be estimated by OLS, GLS, or FGLS. In addition, the selection method is also based on the presence or absence of correlation between the residuals in the ASEAN countries.

To test the structure of the residuals of variance-covariance of fixed effects model, it was used Mutiplier Lagrange test (LM). The null hypothesis used is the variance-covariance structure which is homoscedastic with a test level of 5 percent. Based on the results of a calculation, the value of $\mathrm{LM}=51.3809>$ $\chi^{2}(0.05 ; 5)=11.0704$, means that it reject $\mathrm{H}_{\mathrm{o}}$ for the value of LM is greater than the value of the table. This means that, with a confidence level of 95 percent can be concluded that the structure of the residuals of variance-covariance of the fixed effects models are heteroscedastic.

If the structure of the residuals of variance-covariance of the fixed effects models is heteroscedastic, further it will be conducted the test to determine whether the structure of the residuals of variance-covariance of the fixed effects model is heteroscedastic is correlated (cross-sectional correlation) or not across to the residual in such ASEAN countries. The test statistic used is $\lambda_{\mathrm{LM}}$ Test developed by Breusch and Pagan with the null hypothesis between the residual of the companies of businesses and industries owned by the Indonesian government are not correlated and the test level of 5 percent.

Based on the results of a calculation, the value of $\lambda_{\text {LM }}=18.5409<\chi^{2}(0,05,15=$ 24.9957 , then it does not reject $\mathrm{H}_{0}$ for the value of $\lambda_{\mathrm{LM}}$ is smaller than the value of table. That is, the structure of the residuals of variance-covariance of fixed effects models is heteroscedastic and there is no correlation between the residuals of individuals. Thus, based on the selection of the best models, it is obtained that fixed effects models with variance-covariance structure is heteroscedastic without cross-sectional correlation (GLS). So the estimation of fixed effects models that have been obtained previously must be re-estimated again using cross section weight estimation.

\section{Classical Assumption Test and Statistics Test}


Results of testing the assumptions of normality using the Jarque-Berra test statistics can be found in appendix, pvalue for each individual of a company is greater than $\alpha=0.05$, then the decision is not reject $\mathrm{H}_{0}$, That is, the residuals of the selected regression model has the normal distribution.

Homoscedasticity assumptions have been fulfilled with estimation using cross-section weight estimate. While non-autocorrelation assumption had to be fulfilled because the GLS of panel data research has combined the cross-section and time series data.

The coefficient value of determination of R2 is high and many significant variables. With this approach can be stated that there is no multicolinearity in the model.

There are several statistical tests such as the coefficient of determination (R2), the F-statistic test, and T-statistics test. To see if the independent variables are used together significantly affect the dependent variables, then it is used the simultaneous test with Fisher's statistical test ( $\mathrm{F}$ test), table of estimator model estimation and statistical test as the results of the study will be presented on the sub-section in the front part.

\section{Determinants of FDI Inflows}

Determinants coefficient estimator of FDI inflows of the research results are presented in Table 2 as follows:

The chosen regression model has a relatively high coefficient of determination, amounting to 81.96 percent. The value of the coefficient of determination is explained that 81.96 percent of the variation of FDI inflows in six ASEAN countries during the period of 1998- 2016 is able to be explained by four independent variables which are used while the remaining is amounted to 18.04 percent is explained by other variables outside of the model.

Table 1. Estimator Coefficient of FDI Inflows

\begin{tabular}{|c|c|c|c|c|}
\hline variable & coefficient & Std, Error & t-Statistic & prob, \\
\hline $\mathrm{C}$ & -0.088494 & 0.014583 & -6.068249 & $0.0000 *$ \\
\hline LNCPI & 0.006190 & 0.002047 & 3.023894 & $0.0031 *$ \\
\hline LNEFI & 0.013174 & 0.003996 & 3.296878 & $0.0013 *$ \\
\hline RASIO GDP & 2.398273 & 0.212654 & 11.27783 & $0.0000 *$ \\
\hline UNEMP & -0.000157 & 0.000175 & -0.900655 & 0.36990 \\
\hline \multicolumn{5}{|c|}{ Fixed Effects (Cross) } \\
\hline INA & 0.016999 & & & \\
\hline MAL & -0.002434 & & & \\
\hline PHI & 0.013185 & & & \\
\hline SIN & -0.055301 & & & \\
\hline THA & 0.008015 & & & \\
\hline VIE & 0.019537 & & & \\
\hline \multicolumn{5}{|c|}{ Weighted Statistics } \\
\hline$\overline{R \text {-squared }}$ & 0.819638 & \multicolumn{2}{|c|}{ Mean dependent var } & 0.009264 \\
\hline Adjusted R-squared & 0.804029 & \multicolumn{2}{|c|}{$S, D$, dependent var } & 0.007924 \\
\hline$S, E$, of regression & 0.004014 & \multicolumn{2}{|c|}{ Sum squared resid } & 0.001675 \\
\hline F-statistic & 52.51298 & \multicolumn{2}{|c|}{ Durbin-Watson stat } & 1.229905 \\
\hline$\overline{P r o b}$ (F-statistic) & 0.000000 & & & \\
\hline
\end{tabular}

Description: * significant at the 5\%

Source: E-views 9, mixed (2018) 
From Table 1, it can be seen that p-value or statistical $\mathrm{F}$ prob is smaller than 0.05 test level, so that can be declared at least one of the independent variables (four variables) simultaneously influence the dependent variable is FDI inflows models.

As for knowing whether the independent variables individually significant effect on the dependent variable, we used the partial test statistics ( $t$ test). The identification results of statistical t-test showed that with a significance level of 5 per cent, there are 3 independent variables that significantly influence the FDI inflows in the six countries of ASEAN.

Those three variables are the level of corruption, the level of economic freedom and per capita income. Variable of corruption perception index has a positive influence on FDI inflows, but means that the level of corruption has a negative and significant impact on FDI inflows. Variable of the levels of economic freedom and per capita income has a positive and significant impact on FDI inflows, while the unemployment level variables proved to have a negative effect but not significant to FDI inflows in six ASEAN countries during the period of 1998-2016.

Here is an estimator model estimation of FDI inflows for the six ASEAN countries were obtained:

$$
\begin{aligned}
& \text { RasioFDI }_{\text {it }}=\propto+ \\
& \beta_{1} \text { 0,006190LnCPI } \\
& \text { 2,398273 } \text { RasioGDPCap }_{\text {it }}-0,00013174 \operatorname{Ln} 2
\end{aligned}
$$

Corruption perception index has a positive and significant impact on FDI inflows to the variable coefficient value of 0.006190 . That is, every 1 percent of the increase in the corruption perception index (the net of corruption) then it will cause an increase in the ratio of FDI inflows of a country by 0.006190 , assuming other variables are in a fixed state (ceteris paribus).

These results indicate that when a country is getting rid of corruption, foreign investor confidence will increase to invest in the country. This was in accordance with previous studies by Sambharya (2015), Gasanova (2017) and Taufik (2017) who stated in their research that the low level of corruption can increase the FDI inflows.

Economic freedom index has a positive and significant impact on FDI inflows to the variable coefficient value of 0.013174 . That is, every 1 percent of the increase in the index of economic freedom, it will cause an increase in the ratio of FDI inflows of a country by 0.013174 assuming other variables are in a fixed state (ceteris paribus).

These results indicate that when a country economically more open, then the confidence of foreign investors would increase to invest in the country. This is in line with previous research by Zghidi (2016) and Naanwaab (2016) who states that economic freedom attract the FDI inflows to those countries. Countries that aggressively promote the economic freedom gained the trust of multinational corporations.

The per capita income as a proxy for consumer purchasing power turns to have a positive and significant impact on FDI inflows to the variable coefficient value of 2.398273. That is, any increase in the ratio of income per capita of a country by one unit will cause an increase in the ratio of FDI inflows of a country by 2.398273 , assuming other variables are in a fixed state (ceteris paribus).

For the predictor variable of the unemployment level does not have a significant effect on FDI inflows in six ASEAN countries. It can be concluded that the unemployment level which is used as a proxy for the availability of 
cheap labor has not significantly affect the FDI inflows in six ASEAN countries. Or it could be inferred that the use of the variable toward the unemployment level as a proxy of cheap labor is not yet right. In the direction of this theory has been in accordance with the study by Taufik (2017) who found a negative correlation of unemployment on FDI inflows to the study of 35 countries in the Asian region.

From the determinants model of FDI inflows, it is obtained the independent variables that provide the most dominant influence on FDI inflows is variable of the per capita income. This is indicated by the value of the variable coefficient of per capita income is the biggest variable coefficient value of the FDI inflows, which amounted to 2.398273 , which means that the great opportunities for a country to increase the FDI inflows to the maximum is conducted by increasing its GDP per capita.

\section{Conclusion}

According to the analysis carried out on the variables that affect the FDI inflows in six ASEAN countries, it is obtained the following conclusions:

1. From the descriptive analysis, it can be showed that FDI inflows in six ASEAN countries generally increased in each year. Although sometimes it is a bit fluctuative, but as a whole it increased in each country during the period of 1998-2016. Singapore became the most dominant nation of its FDI inflows and also the most clean of corruption.

2. The level of corruption has a negative and significant effect on the determinants of FDI inflows, while the level of economic freedom and per capita income has a significant positive effect on the determinants of FDI inflows in six ASEAN countries.

3. Unemployment is not a statistically significant affect the FDI inflows in six ASEAN countries.

\section{Recommendation}

Based on the analysis that has been done, there are some recommendations that can be submitted as follows:

1. It is a role for government in six ASEAN countries to create and improve the good economic situation with high per capita incomes to continue to attract foreign investors to invest.

2. Governments of six ASEAN countries need to increase transparency and economic freedom to continue to maintain the inflow of foreign capital into the country.

3. It is needed to increase the performance and the law control to reduce the level of corruption and corrupt behaviors within a country, because it can reduce the interest of investors to invest in the country.

4. Singapore's success in maintaining its value of per capita income, the level of its economic freedom and the level of corruption at high levels may be used as a model by other ASEAN countries.

5. There are still many other factors that affect foreign investment that is interesting to study, such as the quality of infrastructure, the level of a country's security, ease of doing business, as well as the other proxy.

\section{References}

Badan Pusat Statistik. 2016. Buku Pedoman Survei Angkatan Kerja Nasional. Jakarta.

Callen, T. 2008. Back to Basic. What is Gross Domestic Product? Finance \& Development., IMF. .

Gasanova, A. Et Al. 2017. The Assessment of Corruption Impact on the Inflow of Foreign Direct Investment [journal]. AIP Conference Proceedings. 2017, Vol. 1836 Issue 1, p1-4.

Corruption Perception Index. 1999-2017. Global Corruption Report, Transparency International. 
Greene, WH. 2012. Econometric Analysis. Seventh Edition. EssexEngland: Pearson.

Key Indicators for Asia and the Pacific. 2017. Asian Development Bank.

Mankiw, NG. 2007. Makroekonomi. Edisi Keenam. Jakarta : Erlangga.

Naanwaab, C. 2016. Economic Freedom, Human Capital and Foreign Direct Investment [journal]. Journal of Developing Areas. Winter2016, Vol. 50 Issue 1, p407-424. 18p.

Proenca, S. 2005. Demand for Tourism in Portugal : A Panel Data Approach [Discussion Paper February N0.29]

Salvatore, D. 2014. Ekonomi Internasional. Edisi ke-9. Salemba Empat.

Sambharya, RB. 2015. Does economic freedom in host countries lead to increased foreign direct investment?[journal].

Competitiveness Review. 2015, Vol. 25 Issue 1, p2-24. 23p.

Subasat, T. 2013. Governance and Foreign Direct Investment in Latin America: A Panel Gravity Model Approach. Latin American Journal of Economics. May2013, Vol. 50 Issue 1, p107-131

Subekti, AH. 2013. Dampak Korupsi dan Variabel Ekonomi Lainnya Terhadap Pertumbuhan Ekonomi Sepuluh Negara ASEAN + 3[skripsi]. Bogor (ID): Institut Pertanian Bogor.

Tandelilin, E. 2010. Portofolio dan Investasi. Yogyakarta: Kanisius.

Todaro, MP. Smith, SC. 2006. Pembangunan Ekonomi Edisi Kesembilan Jilid 1. Jakarta:Erlangga

World Investment Report. 1999-2016. UNCTAD (United Nation Conference on Trade and Development). New York and Geneva: United Nations.

Taufik, AF. 2017. Analisis Pengaruh Corporate Tax Terhadap FDI Performances: Studi Pada 35 Negara di Kawasan Asia [skripsi].
Bogor (ID): Institut Pertanian Bogor.

Verbeek, M. 2004. A Guide To Modern Econometrics. Second Edition. West Sussex, England: John Wiley $\&$ Sons, Ltd.

Zghidi, N. 2016. Does Economic Freedom Enhance the Impact of Foreign Direct Investment on Economic Growth in North African Countries? A Panel Data Analysis [journal] African Development Review. Maret 2016, Vol. 28 Issue 1, p64

\section{Biographies}

\section{Iqbal Firdaus}

born in Lhoksumawe January 18, 1988, employee of BPS city Lhokseumawe, last education Jakarta College of Statistics.

\section{Sri Mulatsih}

born May 25 196, industrial socioeconomic expertise, economic development and environmental resource economics.

\section{Iskandar Ahmaddien}

Iskandar Ahmaddien, SST, SE, MM. Born in Medan, February 20, 1987. Now working at the Central Java Provincial Statistics Agency and Lecturer at Sangga Buana University, Bandung. Completed D-IV education at the College of Statistics, S1 Faculty of Economics, AsSyafi'iyah Islamic University and Masters in Open University Management 